\title{
FORMULASI PAKAN BUATAN DENGAN BAHAN BAKU RUMPUT LAUT UNTUK PERTUMBUHAN ABALON, Haliotis squamata
}

\author{
Nyoman Adiasmara Giri", Muhammad Marzuqi, Ibnu Rusdi, dan Wawan Andriyanto
}

Balai Besar Penelitian dan Pengembangan Budidaya Laut

\begin{abstract}
ABSTRAK
Abalon merupakan salah satu jenis moluska laut yang memiliki potensi ekonomis untuk dikembangkan usaha budidayanya. Teknologi pembenihan abalon, Haliotis squamata telah dikembangkan dan berhasil memproduksi benih secara massal. Selain benih, ketersediaan pakan yang sesuai sangat menentukan keberhasilan budidaya pembesaran abalon. Selain makan pakan segar berupa makroalga, abalon juga dapat menerima pakan buatan dengan baik. Penelitian ini bertujuan untuk mendapatkan formula pakan dengan bahan baku tepung rumput laut untuk pertumbuhan $H$. squamata. Tiga pakan percobaan diformulasi dengan proporsi tepung rumput laut Ulva sp., Gracilaria sp., dan Sargassum sp. yang berbeda dibuat berbentuk remah dengan kandungan protein dan lemak yang sama. Sebagai kontrol digunakan pakan Gracilaria sp. segar asal tambak. Sebanyak 16 buah bak beton berukuran 2,0 m x 0,5 m x 0,5 m dengan ketinggian air 25 $\mathrm{cm}$ dan dilengkapi dengan aerasi digunakan sebagai wadah percobaan. Benih abalon hasil pembenihan di hatcheri dengan ukuran bobot 5,30 $\pm 1,07 \mathrm{~g}$; panjang cangkang 3,35 \pm 0,29 cm ditebar dengan kepadatan 388 ekor per bak. Abalon diberi pakan percobaan dua kali sehari selama 168 hari. Jumlah pakan disesuaikan dengan respons makan dari abalon. Percobaan menggunakan rancangan acak lengkap dengan empat perlakuan pakan dan setiap perlakuan terdiri atas empat ulangan. Hasil percobaan menunjukkan bahwa pertumbuhan abalon yang diberi pakan buatan tidak berbeda nyata, tetapi pakan dengan proporsi tepung Ulva sp. 35\% cenderung memberikan pertumbuhan yang lebih baik. Pertumbuhan abalon terbaik diperoleh pada perlakuan kontrol. Kandungan protein daging abalon dipengaruhi oleh pakan percobaan. Kandungan protein daging abalon yang diberi pakan buatan signifikan lebih tinggi dibandingkan dengan kontrol.
\end{abstract}

KATA KUNCI: abalon; formulasi pakan; pertumbuhan; rumput laut

ABSTRACT: Formulation of compounded feed by using seaweed as raw material for grow-out of abalone Haliotis squamata. By: Nyoman Adiasmara Giri, Muhammad Marzuqi, Ibnu Rusdi, and Wawan Andriyanto

Hatchery technology for abalone Haliotis squamata has been developed successfully for mass production of seed. In addition to seed supply, availability of appropriate feed largely determines the success of abalone aquaculture development. Beside to eating fresh food of macroalgae, abalone can also accept compounded feed properly. This research aimed to find out feed formulation with seaweed flour as raw material for the growth of $\mathrm{H}$. squamata. Three experimental feeds were prepared with the different proportions of seaweed flour of Ulva sp., Gracilaria sp. and Sargassum sp. All feed had the same protein and fat content, and were prepared as dry flake. Fresh Gracilaria verrucosa was used as the control feed. As many as 16 concrete tanks of $2.0 \mathrm{~m} \times 0.5 \mathrm{~m} \times 0.5 \mathrm{~m}$ with water depth of $25 \mathrm{~cm}$ were used in the experiment. Hatchery produced juvenile abalone of $1.07 \pm 5.30 \mathrm{~g}$ weight and $3.35 \pm 0.29 \mathrm{~cm}$ shell length were stocked with the density of 388 juveniles in each tank. Abalone was fed experimental feed twice a day. The experiment was designed with completely randomized design with four treatments and four replications. The experiment results show that the growths of abalone fed compounded feed were not significantly different $(P>0.05)$, however abalone fed compounded feed containing 35\% Ulva sp. flour tended to give better growth performance. The best growth was obtained on abalone fed fresh Garcilaria verrucosa. Protein content of abalone was influenced by experimental feed. The protein content of abalone fed compounded feed was significantly higher compared to the control.

KEYWORDS: abalone; feed formulation; growth; seaweed

\# Korespondensi: Balai Besar Penelitian dan Pengembangan Budidaya Laut. Jl. Br. Gondol Kec. Gerokgak Kab. Buleleng, Kotak Pos 140, Singaraja, Bali 81101, Indonesia.

Tel.: + (0362) 92272; 92271

E-mail: adiasmaranyoman@yahoo.com 


\section{PENDAHULUAN}

Abalon merupakan salah satu jenis moluska laut yang memiliki potensi ekonomis untuk dikembangkan budidayanya. Permintaan dunia terhadap abalon mengalami peningkatan dari tahun ke tahun. Negara penghasil abalon dari budidaya di antaranya Cina, Jepang, Taiwan, Afrika Selatan, Australia, Amerika Serikat, Meksiko, Irlandia, Islandia, Australia, dan Selandia Baru (Hahn, 1989; Gordon \& Cook, 2001). Di alam dilaporkan terdapat sekitar 100 spesies abalon yang berasal dari genus Haliotis, namun hanya sekitar 10 spesies yang memiliki nilai komersil (Takashi, 1980).

Teknologi pembenihan dua spesies abalon Haliotis asinina dan Haliotis squamata telah dikembangkan di Indonesia. Aplikasi teknologi pembenihan abalon, $H$. squamata telah berhasil memproduksi benih secara massal di hatcheri dengan sintasan berkisar 3,3\%-18,4\% sampai benih umur dua bulan (Susanto et al., 2009). Benih dari hatcheri juga telah berhasil didederkan dengan diberi pakan makroalga dan pakan buatan (Susanto et al., 2010). Dengan tersedianya benih ini mendorong dikembangkannya usaha budidaya pembesaran abalon, baik pembesaran di laut maupun dalam bak di darat. Uji coba pembesaran abalon di laut dengan beberapa metode dan diberi pakan makroalga menunjukkan hasil yang baik (Giri et al., 2014).

Secara alami di laut abalon memanfaatkan makroalga seperti Laminaria sp. (alga coklat), Gracilaria sp. (alga merah), Ulva sp. (alga hijau), dan alga makro lainnya sebagai makanannya. Giri et al. (2014) melaporkan abalon, $H$. squamata yang diberi pakan campuran Gracilaria sp. dan Ulva sp. dengan proporsi 60:40 menghasilkan pertumbuhan terbaik dibandingkan dengan yang proporsi 100:0 dan 80:20. Hasil ini juga menunjukkan bahwa pertumbuhan abalon meningkat dengan meningkatnya proporsi Ulva sp. dalam pakan. Ketersediaan makroalga yang cukup dan kontinu menjadi perhatian tersendiri untuk pengembangan budidaya abalon. Hasil penelitian menunjukkan bahwa beberapa spesies abalon seperti $H$. squamata (Marzuqi et al., 2012), Haliotis midae (Britz, 1997; Goosen et al., 2014), H. asinina (Bautista-Teruel \& Millamena, 1999), Haliotis laevigata (Lange et al., 2014), dan Haliotis fulgens (Gomes-Montes et al., 2003; Garcia-Esquivel et al., 2007) juga dapat memanfaatkan pakan buatan berupa pelet kering sebagai pakannya dan memberikan respons pertumbuhan yang baik. Giri et al. (2015) melaporkan bahwa respons pertumbuhan $H$. squamata yang diberi pakan pelet kering dari bahan baku rumput laut masih lebih rendah dibandingkan dengan yang diberi pakan Gracilaria sp. segar asal tambak. Namun demikian, juga dilaporkan bahwa pakan pelet kering dari campuran tepung rumput laut Gracilaria sp. tambak dengan Ulva sp. atau campuran Gracilaria sp. tambak dengan Sargassum sp. memberikan respons pertumbuhan yang baik. Beberapa faktor yang diduga menyebabkan respons pertumbuhan abalon yang diberi pelet kering ini kurang baik di antaranya adalah palatabilitas pelet dan komposisi nutrien pakan. Untuk itu, pada percobaan ini dibuat formula pakan dengan mengoptimalkan proporsi dari tepung rumput laut Ulva sp., Gracilaria sp. asal tambak dan Sargassum sp. dengan tujuan mendapatkan formula pakan berbahan baku rumput laut yang sesuai untuk mendukung budidaya pembesaran $H$. squamata. Ulva sp. memiliki kandungan protein tertinggi di antara rumput laut tersebut (Giri et al., 2015) sehingga diharapkan dapat menjadi sumber protein pakan abalon.

\section{BAHAN DAN METODE}

Rumput laut sebagai bahan baku pakan diperoleh dari beberapa lokasi berbeda. Ulva sp. diambil dari perairan Benoa (Kabupaten Badung, Bali), Gracilaria sp. tambak dari Situbondo (Jawa Timur), Gracilaria sp. laut dari perairan pantai Gondol (Kabupaten Buleleng, Bali), dan Sargassum sp. dari perairan Pantai Pekutatan (Jembrana, Bali). Rumput laut dibilas dengan air tawar dan selanjutnya dikeringkan dalam oven pada suhu $70^{\circ} \mathrm{C}$. Rumput laut kering dibuat menjadi tepung dan disimpan dalam cold storage sebelum digunakan untuk pembuatan pakan percobaan.

Pada percobaan ini dibuat tiga pakan yang diformulasi menggunakan tepung rumput laut Ulva sp., Gracilaria sp. asal tambak, Gracilaria sp. laut dan Sargassum sp. dengan proporsi yang berbeda dan satu pakan kontrol berupa rumput laut Gracilaria sp. segar asal tambak. Pada formulasi pakan juga ditambahkan tepung ikan dan tepung kedelai untuk mendapatkan kandungan protein pakan percobaan yang ditentukan (Tabel 1). Pakan dibuat dalam bentuk remah (flake) kering. Semua bahan pakan, kecuali karagenan (binder) dicampur merata. Karagenan terlebih dahulu dilarutkan dalam air sampai merata dan dimasak sampai terbentuk gel. Campuran bahan pakan dicampur dengan karagenan yang telah dimasak dan diaduk menggunakan blender sampai merata. Adonan kemudian dituangkan dalam wadah aluminium, diatur ketebalannya dan dikeringkan dalam oven pada suhu $70^{\circ} \mathrm{C}$ sampai kering. Pakan kering disimpan dalam refrigerator sebelum dan selama dimanfaatkan untuk percobaan.

Pada percobaan ini digunakan 16 buah bak beton berukuran 2,0 $\mathrm{m}$ x 0,5 $\mathrm{m}$ x 0,5 $\mathrm{m}$ dengan ketinggian air $25 \mathrm{~cm}$. Bak dilengkapi dengan sistem air mengalir 
Tabel 1. Komposisi (g/100 g pakan) dan hasil analisis proksimat pakan percobaan Table 1. Composition of experimental diet $(\mathrm{g} / 100 \mathrm{~g}$ diet) and its proximate composition

\begin{tabular}{|c|c|c|c|c|}
\hline & \multirow{2}{*}{$\begin{array}{c}\text { Bahan } \\
\text { Ingredients }\end{array}$} & \multicolumn{3}{|c|}{$\begin{array}{l}\text { Pakan percobaan } \\
\text { Experimental diets }\end{array}$} \\
\hline & & Pk-1 & Pk-2 & Pk-3 \\
\hline & Tepung Ulva sp. (Ulva sp. meal) & 25 & 35 & 45 \\
\hline & $\begin{array}{l}\text { Tepung Gracilaria sp. tambak } \\
\text { Gracilaria sp. meal from the pond }\end{array}$ & 20 & 20 & 20 \\
\hline & $\begin{array}{l}\text { Tepung Gracilaria sp. laut } \\
\text { Gracilaria sp. meal from the sea }\end{array}$ & 12 & 8 & 4 \\
\hline & Tepung Sargassum sp. (Sargassum sp. meal) & 7 & 4 & 1 \\
\hline & Tepung ikan (Fish meal) & 18 & 18 & 18 \\
\hline & Tepung kedelai (Soybean meal) & 8 & 5 & 2 \\
\hline & Vitamin $\operatorname{mix}^{1}$ & 2 & 2 & 2 \\
\hline & Mineral $\operatorname{mix}^{2}$ & 2 & 2 & 2 \\
\hline & Minyak ikan (Fish oil) & 4 & 4 & 4 \\
\hline & Karagenan (Carrageenan) (Binder) & 2 & 2 & 2 \\
\hline & Total & 100 & 100 & 100 \\
\hline & \multicolumn{4}{|c|}{ Komposisi proksimat pakan (Proximate composition) } \\
\hline & Kadar air (Moisture ) (\%) & 5.39 & 7.16 & 8.95 \\
\hline & Protein (\% DM) & 25.09 & 24.96 & 24.78 \\
\hline & Lemak (Lipid) (\% DM) & 6.72 & 6.60 & 6.43 \\
\hline & Kadar abu (Ash) $(\% \mathrm{DM})$ & 36.05 & 36.60 & 36.73 \\
\hline & Serat kasar (Fiber) (\% DM) & 20.00 & 19.94 & 20.96 \\
\hline & Karbohidrat (Carbohydrate ) (\% DM) & 12.13 & 11.90 & 11.11 \\
\hline & $\begin{array}{l}\text { Koefisien kecernaan pakan } \\
\text { Feed digestibility coeficient (\%) }\end{array}$ & 72.64 & 73.04 & 73.26 \\
\hline & $\begin{array}{l}\text { Koefisien kecernaan protein pakan } \\
\text { Feed protein digestibility coeficient (\%) }\end{array}$ & 85.67 & 86.04 & 85.93 \\
\hline & \multicolumn{4}{|c|}{$\begin{array}{l}\text { Vitamin } \operatorname{mix}(\mathrm{mg} / 100 \mathrm{~g} \text { diet): thiamin- } \mathrm{HCl} 5,0 \text {; riboflavin } 5,0 \text {; Ca-panthothenate } 10,0 \text {; niacin } \\
2,0 \text {; pyridoxin- } \mathrm{HCl} 4,0 \text {; biotin } 0,6 \text {; folic acid } 1,5 \text {; cyanocobalamin } 0,01 \text {; inositol } 200 \text {; p-aminoben- } \\
\text { zoic acid } 5,0 \text {; menadion } 4,0 \text {; b-carotene } 15,0 \text {; calciferol } 1,9 \text {; a-tocopherol } 2,0 \text {; vitamin C-sty } \\
120,0 \text {; choline chloride } 900 \text {. }\end{array}$} \\
\hline 2 & \multicolumn{4}{|c|}{$\begin{array}{l}\text { Mineral mix (mg/100 g diet): } \mathrm{KH}_{2} \mathrm{PO}_{4} 412 ; \mathrm{CaCO}_{3} 282 ; \mathrm{Ca}\left(\mathrm{H}_{2} \mathrm{PO}_{4}\right) 618 ; \mathrm{FeCl}_{3} \cdot 4 \mathrm{H}_{2} \mathrm{O} 166 ; \mathrm{MgSO}_{4} 240 \\
\mathrm{ZnSO}_{4} 9,99 ; \mathrm{MnSO}_{4} 6,3 ; \mathrm{CuSO}_{4} 2 ; \mathrm{CoSO}_{4} .7 \mathrm{H}_{2} \mathrm{O} 0,05 ; \mathrm{KJ} 0,15\end{array}$} \\
\hline
\end{tabular}

$15 \mathrm{~L} /$ menit dan aerasi sebagai pasok oksigen. Benih abalon yang digunakan merupakan hasil pembenihan secara terkontrol di hatcheri dan mempunyai ukuran bobot rata-rata 5,30 $\pm 1,07 \mathrm{~g}$; panjang cangkang 3,35 $\pm 0,29 \mathrm{~cm}$; dan lebar cangkang $2,03 \pm 0,19 \mathrm{~cm}$. Benih abalon ditebar dengan kepadatan 388 ekor per bak (Heath \& Moss, 2009; Badillo et al., 2007). Selama percobaan, abalon pada masing-masing bak diberi salah satu dari empat pakan percobaan sesuai perlakuan dan diberikan sebanyak dua kali sehari untuk pakan kering dan sekali setiap hari untuk pakan segar (kontrol). Jumlah pakan yang diberikan setiap hari disesuaikan dengan respons makan dari abalon.
Pembersihan kotoran dan sisa pakan dilakukan dengan cara pencucian dasar bak setiap hari sebelum pemberian pakan.

Percobaan dirancang menggunakan rancangan acak lengkap dengan empat perlakuan, yaitu tiga macam pakan kering (remah) yang diformulasi dari bahan baku tepung rumput laut dan satu pakan segar rumput laut Gracilaria sp. asal tambak sebagai kontrol. Setiap perlakuan terdiri atas empat ulangan. Setiap dua bulan dilakukan pengukuran bobot, panjang, dan lebar cangkang terhadap 30-50 ekor abalon dari masingmasing unit percobaan untuk mengetahui respons abalon terhadap pakan percobaan. Abalon yang mati 
dicatat setiap hari selama percobaan sebagai dasar untuk menghitung sintasan selama 168 hari percobaan. Contoh daging abalon diambil pada awal dan akhir percobaan, dikeringkan dengan freeze dryer, dan dianalisis komposisi proksimatnya.

Untuk uji kecernaan pakan, pada masing-masing formula pakan ditambahkan indikator kromium oksida $\left(\mathrm{Cr}_{2} \mathrm{O}_{3}\right)$ sebanyak 1\% (Furuichi, 1988). Wadah yang digunakan untuk menentukan kecernaan pakan percobaan adalah bak polikarbonat volume 30 liter yang dilengkapi dengan sistem air mengalir dan aerasi. Sebagai hewan uji digunakan abalon ukuran bobot rata-rata 9,22 $\pm 1,57 \mathrm{~g}$ ditebar dengan kepadatan 30 ekor/bak. Abalon diadaptasikan dengan pakan percobaan selama satu minggu sebelum dilakukan pengumpulan feses. Abalon diberi pakan percobaan secara berlebih 2 kali sehari pada pagi dan sore hari. Sisa pakan dan kotoran dalam bak dibersihkan tiga jam setelah pemberian pakan. Pengumpulan feses dilakukan secara berkala dengan cara penyifonan untuk mencegah terlarutnya nutrien pada feses. Feses dikumpulkan dan disimpan dalam freezer sampai mendapatkan jumlah yang cukup untuk analisis. Feses yang terkumpul dikeringkan dengan oven. Konsentrasi kromium dalam pakan dan feses dianalisis berdasarkan prosedur Takeuchi (1988). Koefisien kecernaan bahan kering dan protein dari pakan percobaan dihitung berdasarkan rumus Takeuchi (1988):

$$
\operatorname{ADC}(\%)=100 \times\left\{1-\left(M_{D} \times A_{F}\right) /\left(M_{F} \times A_{D}\right)\right\}
$$

di mana: $\quad \mathrm{ADC}=$ Apparent digestibility coefficient (koefisien kecernaan) dari bahan kering atau protein kasar, $M_{D}$ dan $M_{F}$ berturut-turut adalah kadar kromium dalam pakan dan feses, $A_{D}$ dan $A_{F}$ berturut-turut adalah kadar protein dalam pakan dan feses

Komposisi proksimat pakan percobaan dianalisis di Laboratorium Nutrisi dan Pakan, Balai Besar Penelitian dan Pengembangan Budidaya Laut, Gondol berdasarkan metode AOAC (1990) dan Takeuchi (1988). Kadar air ditentukan dengan metode gravimetri, kandungan protein ditentukan dengan metode Kjeldahl, kadar lemak dengan metode ekstraksi menggunakan kloroform-metanol dan gravimetri, kadar abu dengan metode gravimetri setelah pembakaran bahan dalam tanur pada suhu $550^{\circ} \mathrm{C}$. Serat kasar ditentukan dengan gravimetri setelah contoh bahan dimasak pada larutan asam dan basa. Karbohidrat (BETN) dihitung berdasarkan formula $\{100$ - (kadar air + kadar protein + kadar lemak + kadar abu + kadar serat kasar)\}. Kandungan asam amino abalon dianalis di Laboratorium Terpadu Institut Pertanian Bogor menggunakan High Performance Liquid Chromatography (HPLC) merek Shimadzu type 20 dengan kolom ultra techspere dan detektor flouresens.
Untuk mengetahui respons abalon terhadap pakan percobaan, data bobot akhir, pertambahan bobot, panjang dan lebar cangkang, sintasan, serta komposisi proksimat daging abalon dianalisis ragam (ANOVA) dan dilanjutkan dengan uji Tukey pada selang kepercayaan 95\% (Steel \& Torrie, 1980).

\section{HASIL DAN BAHASAN}

Respons abalon yang diberi pakan percobaan selama 168 hari disajikan pada Tabel 2. Sintasan abalon berkisar antara 91,3\%-93,5\% dan tidak dipengaruhi oleh pakan percobaan termasuk pakan kontrol $(P>0,05)$. Beberapa kematian abalon selama percobaan terjadi setelah dilakukan pengukuran karena terjadi luka saat penanganan. Pada percobaan pendederan abalon $H$. laevigata menggunakan pakan buatan dan Ulva sp., Daume et al. (2007) melaporkan bahwa sintasan abalon yang diberi pakan buatan justru lebih tinggi (77\%-82\%) dibandingkan dengan yang diberikan pakan alga segar (62\%-65\%). Abalon yang diberi pakan percobaan yang diformulasi dengan bahan tepung rumput laut menghasilkan bobot akhir abalon yang tidak berbeda nyata $(P>0,05)$ seperti halnya parameter pertambahan bobot, panjang cangkang, dan lebar cangkang. Namun abalon yang diberi pakan Pk-2 (campuran 35\% Ulva sp., 20\% Gracilaria sp. tambak, 8\% Gracilaria sp. laut dan 4\% Sargassum sp.) cenderung menghasilkan pertambahan bobot, panjang cangkang, dan lebar cangkang yang lebih tinggi dibandingkan dengan yang diberi pakan percobaan Pk-1 dan Pk-3. Secara keseluruhan pertumbuhan yang meliputi bobot akhir, pertambahan bobot, panjang cangkang, dan lebar cangkang abalon yang diberi pakan Gracilaria sp. segar asal tambak adalah lebih tinggi dibandingkan dengan perlakuan pakan lainnya $(\mathrm{P}<0,05)$. Hal yang sama dilaporkan Mai et al. (1995) untuk abalon H. tuberculata dan $H$. discus hanai yang diberi pakan alga merah Palmaria palmata segar tumbuh lebih baik dibandingkan dengan yang diberi pakan pelet kering.

Tanpa memperhatikan proporsi dari masing-masing tepung rumput laut dalam pakan, semua pakan percobaan mempunyai kandungan makronutrien protein $(24,78 \%-25,09 \%)$, lemak $(6,43 \%-6,72 \%)$, dan karbohidrat $(11,11 \%-12,13 \%)$ yang hampir sama (Tabel 1). Pada percobaan sebelumnya Giri et al. (2015) melaporkan bahwa pakan pelet kering dari campuran tepung rumput laut Gracilaria sp. tambak dengan Ulva sp. (2:1) atau campuran Gracilaria sp. tambak dengan Sargassum sp. $(2,3: 1)$ memberikan respons pertumbuhan abalon $H$. squamata yang baik. Namun hasil inipun masih lebih rendah dibandingkan dengan pertumbuhan abalon $H$. squamata yang diberi pakan Gracilaria sp. segar asal tambak. Giri et al. (2014) melaporkan bahwa abalon yang diberi pakan rumput laut segar Gracilaria sp. tambak dan Ulva sp. dengan 
perbandingan 60:40 (setara dengan 2,4:1 bobot kering) menghasilkan pertumbuhan yang baik. Dari hasil beberapa percobaan ini menunjukkan Gracilaria sp., baik dalam bentuk segar maupun tepung kering mempunyai peran penting untuk mendukung pertumbuhan abalon $H$. squamata. Setyono (2006) melaporkan bahwa walaupun abalon $H$. asinina lebih munyukai Gracilaria sp., tetapi pertumbuhan abalon yang hanya diberi pakan Gracilaria sp. hampir sama dengan yang diberi pakan Ulva sp.

Pertumbuhan abalon $H$. asinina terbaik justru diperoleh dengan memberi pakan campuran dari beberapa rumput laut termasuk Gracilaria sp. dan Ulva sp. Stok induk abalon $H$. squamata tumbuh paling baik saat diberikan pakan kombinasi antara Gracilaria sp., Ulva sp., dan Sargassum sp. dibandingkan dengan pemberian pakan hanya salah satu dari rumput laut tersebut (Rusdi et al., 2010). Pendederan benih abalon $H$. squamata menggunakan pakan buatan pelet kering dengan proporsi tepung Ulva sp./tepung Gracilaria sp. 100:0 sampai 50:50 dalam pakan tidak menghasilkan pertumbuhan abalon yang berbeda. Namun pada proporsi tepung Ulva sp./tepung Grcilaria sp. 25:75 justru menghasilkan pertumbuhan abalon yang lebih rendah (Marzuqi et al., 2012).

Pada percobaan ini ketiga pakan diformulasi dengan kandungan tepung Gracilaria sp. tambak yang sama, yaitu $20 \%$ dan ternyata menghasilkan pertumbuhan yang tidak berbeda nyata. Peningkatan kandungan tepung Ulva sp. dari 25\% sampai 45\% dengan kandungan tepung Gracilaria sp. tambak yang sama sebanyak 20\% dimaksudkan untuk mendapatkan kandungan protein pakan yang lebih tinggi. Tepung Ulva sp. mempunyai kandungan protein lebih tinggi $(\sim 23,6 \%)$ dibandingkan dengan tepung Gracilaria sp. tambak $(15,2 \%)$ dan tepung Sargassum sp. (7,9\%) (Giri et al., 2014). de Padua et al. (2004) juga melaporkan kandungan protein Ulva lactuca dan Ulva fasciata masing-masing mencapai $15,23 \%-18,35 \%$ dan $13,30 \%-16,13 \%$. Nilai yang bervariasi ini diduga dipengaruhi oleh musim dan lingkungan tumbuhnya. Selain kandungan proteinnya yang lebih tinggi, tepung Ulva sp. juga dilaporkan mengandung senyawa bioaktif dan antioksidan yang berperan dapat menekan mortalitas abalon $H$. laevigata akibat meningkatnya suhu air pada musim panas (Lange et al., 2014). Ulva sp. juga dilaporkan mempunyai komposisi asam amino esensial yang paling baik dibandingkan Gracilaria sp. tambak, Gracilaria sp. laut dan Sargassum sp. (Giri et al., 2015). Dengan kandungan protein lebih tinggi dan komposisi asam amino esensial yang lebih baik dibandingkan jenis makroalga lainnya, serta adanya kandungan bioaktif dan antioksidan, maka Ulva sp. dapat merupakan salah satu bahan baku pakan potensial untuk abalon.

Informasi kebutuhan nutrien pakan untuk abalon H. squamata belum tersedia. Namun kandungan protein pakan yang memberikan pertumbuhan terbaik pada beberapa jenis abalon telah dipublikasikan dan dapat dijadikan acuan pada formulasi pakan abalon. Bautista-Teruel \& Millamena (1999) melaporkan bahwa pakan dengan level protein $27 \%$ adalah optimum untuk abalon $H$. asinina. Rahman et al. (2012) melaporkan bahwa pakan pelet dengan $34 \%$ protein dan $4 \%$ lemak menghasilkan pertumbuhan abalon hibrida ( $H$. discus hannai x $H$. sieboldii) yang baik. Abalon $H$. midae tumbuh baik dengan pakan buatan yang mengandung $30 \%$ protein dan 5\% lemak (Britz et al., 1997). Sementara itu, Mai et al. (1995) melaporkan abalon $H$. tuberculata dan $H$. discus hanai yang diberi pakan pelet dengan kandungan protein 25\% dan 3,11\%-7,09\% lemak pertumbuhannya lebih rendah dibandingkan dengan yang diberi pakan alga merah Palmaria palmata segar. Dari beberapa informasi tersebut terlihat bahwa kebutuhan protein untuk pertumbuhan beberapa spesies abalon sangat bervariasi, berkisar antara 25\% sampai 34\%. Variasi nilai ini memang dapat terjadi karena beda bahan baku pakan yang digunakan, manajemen pemberian pakan, serta jenis abalon. Kandungan protein pakan yang berbeda memengaruhi jumlah konsumsi pakan oleh abalon. Bansemer et al. (2015) menemukan bahwa abalon $H$. laevigata yang diberi pakan dengan kandungan protein berbeda $(27 \%$,

Tabel 2. Performa pertumbuhan dan sintasan abalon yang diberi pakan percobaan ${ }^{1)}$

Table 2. Growth performance and survival of abalone fed by experimental diets ${ }^{1)}$

\begin{tabular}{cccccc}
\hline $\begin{array}{c}\text { Pakan percobaan } \\
\text { Experimental diets }\end{array}$ & $\begin{array}{c}\text { Bobot akhir } \\
\text { Final weight }(\mathbf{g})\end{array}$ & $\begin{array}{c}\text { Pertambahan bobot } \\
\text { Weight gain }(\%)\end{array}$ & $\begin{array}{c}\text { Panjang cangkang } \\
\text { Shell lenght }(\mathbf{c m})\end{array}$ & $\begin{array}{c}\text { Lebar cangkang } \\
\text { Shell width }(\mathbf{c m})\end{array}$ & $\begin{array}{c}\text { Sintasan } \\
\text { Survival }(\%)\end{array}$ \\
\hline Pk-1 & $8.33 \pm 1.57^{\mathrm{a}}$ & $66.5 \pm 14.0^{\mathrm{a}}$ & $3.58 \pm 0.36^{\mathrm{a}}$ & $2.33 \pm 0.17 \mathrm{a}$ & $92.6 \pm 2.4^{\mathrm{a}}$ \\
$\mathrm{Pk}-2$ & $8.90 \pm 1.54^{\mathrm{a}}$ & $73.6 \pm 15.7^{\mathrm{ab}}$ & $3.88 \pm 0.21^{\mathrm{ab}}$ & $2.38 \pm 0.15^{\mathrm{ab}}$ & $91.9 \pm 1.4^{\mathrm{a}}$ \\
$\mathrm{Pk}-3$ & $8.09 \pm 0.89^{\mathrm{a}}$ & $68.7 \pm 18.5^{\mathrm{a}}$ & $3.65 \pm 0.21^{\mathrm{a}}$ & $2.18 \pm 0.10^{\mathrm{a}}$ & $91.3 \pm 1.2^{\mathrm{a}}$ \\
Gracilaria sp. & $11.86 \pm 0.16^{\mathrm{b}}$ & $93.0 \pm 13.2^{\mathrm{b}}$ & $4.28 \pm 0.10^{\mathrm{b}}$ & $2.60 \pm 0.08^{\mathrm{b}}$ & $93.5 \pm 3.8^{\mathrm{a}}$ \\
\hline
\end{tabular}

Nilai dalam kolom yang sama diikuti oleh huruf superskrip yang berbeda menunjukkan nilai berbeda nyata $(\mathrm{P}<0,05)$ 
$30 \%, 33 \%$, dan 37\%) ternyata jumlah konsumsi pakannya lebih tinggi untuk pakan yang mempunyai kandungan protein yang lebih rendah. Hal yang sama juga dilaporkan Giri et al. (2015) untuk abalon, H. squamata, yang mana tingkat konsumsi pakan rumput laut Gracilaria sp. segar yang mempunyai kadar protein 15,20\% (bobot kering) ternyata jauh lebih tinggi (91 mg bobot kering/individu/hari) dibandingkan dengan yang diberi pakan pelet kering dengan kandungan protein 28\%-31\% (49-50 mg bobot kering/individu/hari). Dari kedua jumlah konsumsi pakan yang berbeda ini ternyata total proteinnya hampir sama, yaitu mencapai 14-15 mg protein/individu/hari. Kedua hasil percobaan tersebut menunjukkan abalon akan memenuhi kebutuhan proteinnya dengan mengonsumsi jumlah pakan yang berbeda.

Pada Tabel 3 disajikan komposisi proksimat daging abalon setelah diberi pakan percobaan selama 168 hari. Kandungan bahan kering, lemak, dan abu daging abalon setelah diberi pakan percobaan tidak berbeda nyata $(\mathrm{P}>0,05)$. Daging abalon yang diberi pakan buatan mempunyai kandungan protein yang lebih tinggi dan berbeda nyata $(\mathrm{P}<0,05)$ dibandingkan dengan daging abalon yang diberi pakan Gracilaria sp. segar. Namun demikian, kandungan protein ketiga grup daging abalon yang diberi pakan buatan tidak berbeda nyata $(\mathrm{P}>0,05)$, yang menunjukkan perbedaan proporsi tepung rumput laut dalam pakan buatan tidak berpengaruh terhadap kandungan protein daging abalon. Hasil yang sama dilaporkan Cho \& Kim (2012) untuk abalon $H$. discus hannai yang diberi pakan pelet kering dengan sumber protein tepung ikan, tepung kedelai, dan tepung kepala udang menghasilkan kandungan protein karkas yang lebih tinggi dibandingkan dengan yang diberi pakan makroalga Laminaria japonica. Pada percobaan sebelumnya Giri et al. (2015) melaporkan daging abalon $H$. squamata yang diberi pakan pelet kering dengan sumber protein tepung rumput laut dan tepung ikan mempunyai kandungan protein yang lebih tinggi dibandingkan dengan yang diberi pakan Gracilaria sp. segar. Beberapa hasil percobaan ini membuktikan bahwa komposisi kimia daging abalon dipengaruhi oleh komposisi nutrien pakannya, seperti juga yang dilaporkan Cho et al. (2007), serta Bautista-Teruel \& Millamena (1999) masing-masing untuk abalon $H$. discus hanai dan $H$. asinina. Pada Tabel 4 disajikan komposisis asam amino daging abalon yang diberi pakan buatan dan Gracilaria verrucosa segar, serta asam amino dari stok abalon yang diberi pakan campuran rumput laut segar. Pada Tabel 4 terlihat bahwa secara umum komposisi asam amino daging abalon yang diberi pakan berbeda tidak menunjukkan adanya variasi yang signifikan, kecuali kandungan asam amino glutamat dan glisin lebih rendah pada abalon stok yang diberi pakan campuran Gracilaria sp. dan Ulva sp. Kedua asam amino ini merupakan komponen yang menentukan rasa gurih dari daging abalon, khususnya kandungan glisin dan glutamat dari asam amino bebasnya (Chiou \& Lai, 2002).

Pada formulasi pakan buatan dengan menggunakan kombinasi tepung rumput laut juga ditambahkan tepung ikan dan tepung kedelai. Hal ini diharapkan dapat memberikan keseimbangan nutrien sesuai kebutuhan abalon, di samping untuk mendapatkan kandungan protein pakan yang lebih tinggi. O'Mahoney et al. (2014) pada penelitian evaluasi penggunaan campuran tepung alga makro untuk mendapatkan alternatif bahan baku pakan pengganti tepung ikan melaporkan bahwa campuran tepung makroalga Palmaria palmata, Ulva lactuca, dan Laminaria digitata dengan proporsi 1:1:1 potensial sebagai pengganti tepung ikan untuk pakan abalon $H$. discus hannai. Mai et al. (1994) melaporkan bahwa beberapa makroalga yang biasa digunakan sebagai pakan abalon $H$. discus hannai dan $H$. tuberculata defisien akan asam amino arginin, metionin, histidin, dan treonin. Pada evaluasi komposisi kimia makroalga sebagai pakan $H$. squamata, Giri et al. (2015) melaporkan asam amino esensial metionin dan lisin adalah defisien pada Ulva sp., Gracilaria sp., dan Sargassum sp. Walaupun abalon di alam umumnya makan makrolaga, namun abalon

Tabel 3. Komposisi proksimat daging abalon yang diberikan pakan percobaan ${ }^{1)}$

Table 3. Proximate composition of abalone fed by experimental diets ${ }^{1)}$

\begin{tabular}{lccccc}
\hline $\begin{array}{l}\text { Pakan percobaan } \\
\text { Experimental diets }\end{array}$ & $\begin{array}{c}\text { Bahan kering } \\
\text { Dry matter (\%) }\end{array}$ & $\begin{array}{c}\text { Protein kasar } \\
\text { Crude protein }(\% \mathrm{DM})\end{array}$ & $\begin{array}{c}\text { Lemak } \\
\text { Lipid }(\% \mathrm{DM})\end{array}$ & $\begin{array}{c}\text { Abu } \\
\text { Ash }(\% \mathrm{DM})\end{array}$ & $\begin{array}{c}\text { BETN } \\
\text { NFE (\%) }\end{array}$ \\
\hline $\mathrm{Pk}-1$ & $19.7 \pm 1.1^{\mathrm{a}}$ & $66.4 \pm 1.0^{\mathrm{a}}$ & $7.6 \pm 0.8^{\mathrm{a}}$ & $10.8 \pm 0.5^{\mathrm{a}}$ & $7.4 \pm 0.8^{\mathrm{a}}$ \\
$\mathrm{Pk}-2$ & $19.8 \pm 1.7^{\mathrm{a}}$ & $65.5 \pm 0.2^{\mathrm{a}}$ & $8.1 \pm 0.8^{\mathrm{a}}$ & $9.9 \pm 0.9^{\mathrm{a}}$ & $7.7 \pm 0.6^{\mathrm{a}}$ \\
$\mathrm{Pk}-3$ & $19.0 \pm 0.5^{\mathrm{a}}$ & $66.2 \pm 1.5^{\mathrm{a}}$ & $7.7 \pm 1.5^{\mathrm{a}}$ & $9.6 \pm 0.5^{\mathrm{a}}$ & $7.7 \pm 1.1^{\mathrm{a}}$ \\
Gracilaria sp. & $19.5 \pm 0.4^{\mathrm{a}}$ & $61.6 \pm 1.6^{\mathrm{b}}$ & $6.7 \pm 0.2^{\mathrm{a}}$ & $10.8 \pm 0.8^{\mathrm{a}}$ & $11.4 \pm 1.4^{\mathrm{b}}$ \\
\hline $\begin{array}{l}\text { 1) } \\
\text { Nilai dalam kolom yang sama diikuti oleh huruf superskrip yang berbeda menunjukkan nilai berbeda nyata }\end{array}$ &
\end{tabular}


Tabel 4. Komposisi asam amino abalon yang diberi pakan berbeda (\% w/w)

Table 4. Amino acid composition of abalone fed different diet (\% $\mathrm{w} / \mathrm{w})$

\begin{tabular}{|c|c|c|c|}
\hline $\begin{array}{c}\text { Asam amino } \\
\text { Amino acids (AA) }\end{array}$ & $\begin{array}{l}\text { Diberi pakan pelet } \\
\text { Fed dry pellet }\end{array}$ & $\begin{array}{c}\text { Diberi pakan } \\
\text { Gracilaria sp. } \\
\text { Fed Gracilaria sp. }\end{array}$ & $\begin{array}{l}\text { Stok abalon diberi pakan } \\
\text { Gracilaria sp. dan Ulva sp. } \\
\text { Stock abalone fed } \\
\text { Gracilaria sp. and Ulva sp. }\end{array}$ \\
\hline \multicolumn{4}{|l|}{ AA esensial (AA essential $)$} \\
\hline Leusin (Leucine) & 4.58 & 4.26 & 4.53 \\
\hline Metionin (Methionine) & 1.87 & 1.71 & 1.12 \\
\hline Isoleusin (Isoleucine) & 2.66 & 2.45 & 2.49 \\
\hline Valin (Valine) & 2.72 & 2.51 & 2.82 \\
\hline Arginin (Arganine) & 6.45 & 6.19 & 5.95 \\
\hline Treonin (Threonine) & 2.44 & 2.21 & 2.60 \\
\hline Histidin (Histidine ) & 0.88 & 0.70 & 0.82 \\
\hline Fenilalanin (Phenylalanine) & 2.84 & 2.58 & 2.27 \\
\hline Lisin (Lysine) & 3.52 & 3.18 & 4.11 \\
\hline \multicolumn{4}{|l|}{ AA non-esensial (AA non-essential) } \\
\hline Alanin (Alanine) & 3.60 & 3.69 & 3.58 \\
\hline Asam aspartat (Aspartic acid) & 6.82 & 6.40 & 5.76 \\
\hline Asam glutamat (Glutamin acid) & 12.77 & 12.57 & 9.19 \\
\hline Glisin (Glycine) & 4.56 & 5.12 & 3.56 \\
\hline Serin (Serine) & 3.09 & 2.96 & 2.40 \\
\hline Tirosin (Tyrosine) & 2.27 & 1.93 & 1.93 \\
\hline
\end{tabular}

yang diberi pakan buatan dengan bahan baku tepung ikan, tepung kedelai, atau tepung Spirulina dapat tumbuh dengan baik, dan di antaranya ternyata tepung ikan dilaporkan memberikan respons pertumbuhan yang paling baik untuk abalon $H$. iris (Tung \& Alfero, 2012). Hal ini menunjukkan abalon dapat memanfaatkan protein hewani dengan baik untuk menyusun protein tubuhnya.

\section{KESIMPULAN}

Perbedaan proporsi tepung rumput laut pada formulasi pakan buatan dengan peningkatan kandungan tepung Ulva sp. dalam pakan tidak berpengaruh nyata terhadap pertumbuhan abalon $H$. squamata, tetapi pakan dengan proporsi tepung Ulva sp. $35 \%$ cenderung memberikan pertumbuhan yang lebih baik. Pertumbuhan abalon yang diberi pakan Gracilaria sp. segar adalah terbaik dibandingkan dengan yang diberi pakan buatan. Sebaliknya kandungan protein daging abalon yang diberi pakan buatan signifikan lebih tinggi dibandingkan dengan yang diberi pakan Gracilaria sp. segar.

\section{UCAPAN TERIMA KASIH}

Penelitian ini dibiayai dari DIPA Balai Besar Penelitian dan Pengembangan Budidaya Laut (BBPPBL),
Gondol Tahun 2015. Penulis sampaikan terima kasih kepada teknisi abalon dan teknisi pakan/nutrisi, serta analis Laboratorium Kimia BBPPBL, Gondol atas bantuannya dalam pelaksanaan penelitian ini.

\section{DAFTAR ACUAN}

Association of Official Analytical Chemist (AOAC). (1990). Official methods of analysis. 12th Ed. Washington, D.C. Association of Official Analytical Chemists. p. 1141.

Badillo, L., Segovia, M., \& Bernal, R.S. (2007). Effect of two stocking densities on the growth and mortality of the pink abalone Haliotis corrugata in recirculating and flow-through systems. J. Shellfish Research, 26(3), 801-807.

Bansemer, M.S., Harris, J.O., Qin, J.G., Adams, L.R., Duong, D.N., \& Stone, D.A.J. (2015). Growth and feed utilisation of juvenile greenlip abalone (Haliotis laevigata) in response to water temperatures and increasing dietary protein levels. Aquaculture, 436, 13-20.

Bautista-Teruel, M.N., \& Millamena, O.M. (1999). Diet development and evaluation for juvenile abalone, Haliotis asinina: protein/renergy levels. Aquaculture, 178, 117-126. 
Britz, P.J., Hecht, T., \& Mangold, S. (1997). Effect of temperature on growth, feed consumption and nutritional indices of Haliotis midae fed a formulated diet. Aquaculture, 152, 191-203.

Chiou, T., \& Lai, M. (2002). Comparison of taste components in cooked meats of small abalone fed different diets. Fisheries Science, 68, 388-394.

Cho, S.H., Park, J., Kim, C., \& Yoo, J. (2007). Effect of casein substitution with fishmeal, soybean meal and crustacean meal in the diet of the abalone Haliotis discus hannai Ino. Aquaculture Nutrition, 14, 61-66.

Cho, S.H., \& Kim, D.S. (2012). Effects of feed type and temperature on growth of juvenile abalone, Haliotis discus hannai Ino.J. World Aquaculture Society, 43, 114-119.

Daume, S., Davidson, M., Ryan, S., \& Parker, F. (2007). Comparisons on rearing systems based on algae or formulated feed for juvenile greenlip abalone (Haliotis leavigata).J. Shellfish Research, 26, 729-735.

de Padua, M., Fontoura, P.S.G., \& Mathias, A.L. (2004). Chemical composistion of Ulvaria oxysperma (Kutzing) Bliding, Ulva lactuca (Linnaeus) and Ulva fascita (Delile). Int. J. Brazilian Archives of Bioloby and Technology, 47, 49-55.

Furuichi, M. (1988). Carbohydrate. In Watanabe, T. (Ed.). Fish Nutrition and Mariculture. Departement of Aquatic Biosciences, University of Fisheries. Tokyo, p. 44-55.

Garcia-Esquivel, Z., Montes-Magallon, S., \& GonzalezGomes, M.A. (2007). Effect of temperature and photoperiod on the growth, feed consumption, and biological content of juvenile green abalone, Haliotis fulgens, fed on a balanced diet. Aquaculture, 262, 129-141.

Giri, N.A., Sutarmat, T., Yudha, H.T., Rusdi, I., \& Susanto, B. (2014). Grow-out of abalone Haliotis squamata in floating cages fed different proportions of seaweed and with reduction of stocking density. Indonesian Aquaculture Journal, 9(1), 1521.

Giri, N.A., Marzuqi, M., Astuti, N.W.W., Andriyanto, W., Rusdi, I., \& Andamari, R. (2015). Evaluasi bahan baku pakan dan pengembangan pakan buatan untuk budidaya pembesaran abalon (Haliotis squamata). J. Ris. Akuakultur, 10(3), 379-388.

Gomez-Montes, L., Garcia-Esquivel, Z., D’Abramo, L.R., Shimada, A., Vasquez-Pelaez, C., \& Viana, M.T. (2003). Effect of dietary protein: energy ratio on intake, growth and metabolism of juvenile green abalone, Haliotis fulgens. Aquaculture, 222, 769-780.
Gordon, H.R., \& Cook, P.A. (2001). World abalone fisheries and aquaculture update: supply and market dynamics. J. Shellfish Research, 20, 567-570.

Goosen, N.J., de Wet, L.F., \& Görgens, J.F. (2014). Rainbow trout silage oil as immunity enhancing feed ingredient in formulated diets for South African abalone Haliotis midae. Aquaculture, 430, 2833.

Hahn, K.O. (1989). Artificial induction of spawning and fertilization. In Hahn, K.O. (Ed.). Handbook of Culture of Abalone and other Marine Gastropods. Boca Raton, Florida. CRC Press. Inc. p.53-70.

Heath, P., \& Moss, G. (2009). Is the size grading inportant for farming the abalon Haliotis iris. Aquaculture, 290, 80-86.

Lange, B., Currie, K., Howarth, G.S., \& Stone, D.A.J. (2014). Grape seed extract and dried macroalgae, Ulva lactuca Linnaeus, improve survival of greenlip abalone, Haliotis laevigata Donovan, at high water temperature. Aquaculture, 433, 348-360.

Mai, K., Mercer, J.P., \& Donlon, J. (1994). Comparative studies on the nutrition of two species of abalone, Haliotis tuberculata L. and Haliotis discus hannai Ino. II. Amino acid composition of abalone and six species of macroalgae with an assessment of their nutritional value. Aquaculture, 128, 15-30.

Mai, K., Mercer, J.P., \& Donlon, J. (1995). Comparative studies on the nutrition of two species of abalone, Haliotis tuberculata L. and Haliotis discus hannai Ino. IV. Optimum dietary protein for growth. Aquaculture, 134, 165-180.

Marzuqi, M., Rusdi, I., \& Susanto, B. (2012). Aplikasi pakan buatan pada pemeliharaan benih abalon (Haliotis squamata). J. Ris. Akuakultur, 7, 237-245.

O’Mahoney, M., Rice, O., Mouzakitis, G., \& Burnell, G. (2014). Towards sustainable feeds for abalone culture: Evaluating the use of mixed species seaweed meal in formulated feeds for the Japanese abalone, Haliotis discus hannai. Aquaculture, 430, 9-16.

Rahman, M.M., Kadowaki, S., Linn, S.M., \& Yamada, Y. (2012). Land-based poly-eco-aquaculture of abalone and seaweed in a small scale recirculating system using a recycled freezer container. Bull. Fish. Res. Agen., 35, 77-84.

Rusdi, I., Rahmawati, R., Susanto, B., \&. Giri, I N.A. (2010). Pematangan gonad induk abalon Haliotis squamata melalui pengelolaan pakan. J. Ris. Akuakultur, 5(3), 383-391. 
Setyono, D.E.D. (2006). Food preferences for juvenile tropical abalone (Haliotis asinina). Oseanologi dan Limnologi di Indonesia, 41, 1-14.

Steel, R.G.D., \&. Torrie, J.H. (1980). Principles and procedures of statistics. New York, USA. McGraw Hill. p. 481.

Susanto, B., Rusdi, I., Ismi, S., \& Rahmawati, R. (2009). Pembenihan dan pembesaran abalon (Haliotis squamata) di Balai Besar Riset Perikanan Budidaya Laut, Gondol, Bali. Dalam Prosiding Seminar Nasional Moluska 2; "Moluska Peluang Bisnis dan Konservasi". FPIK-IPB. Bogor, hlm. 149-161.

Susanto, B., Rusdi, I., Ismi, S., \& Rahmawati, R. (2010). Pemeliharaan yuwana abalon (Haliotis squamata) turunan F-1 secara terkontrol dengan jenis pakan berbeda. J. Ris. Akuakultur, 5(2), 199-209.

Takashi. (1980). Abalone and Their Industry in Japan. Ministry of Agriculture, Forestry and Fisheries. Tokyo, p. 165-177.

Takeuchi, T. (1988). Laboratory work-chemical evaluation of dietary nutrient. In Watanabe, T. (Ed.). Fish Nutrition and Mariculture. JICA Kanagawa International Fisheries Training Centre. Tokyo, p. 179-233.

Tung, C., \& Alfaro, A.C. (2012). Alternative protein sources in artificial diets for New Zealand's blackfooted abalone, Haliotis iris, Martyn 1784, juveniles. J. World Aquaculture Society, 43, 1-29. 